\title{
Bowen's disease: Response to topical 5\% imiquimod and cryotherapy
}

\author{
Aryal $E^{1}$, Amatya $A^{2}$, Karn $D^{3}$ \\ ${ }^{1,2}$ Lecturer; ${ }^{3}$ Associate Professor, Department of Dermatology, Kathmandu University Teaching \\ Hospital
}

\begin{abstract}
We present a case of persistent and progressive Bowen's disease (squamous cell carcinoma in situ) in right inner thigh, skin type $\mathrm{V}$ in 65 years age female from Ramechap in 2014. Treatment with imiquimod 5\% cream was effective when applied once a day for three consecutive days for three month followed by maintenance with cryothrerapy for further three month.
\end{abstract}

Keywords: Benign disease, Liquid nitrogen, Cryotherapy, Imiquimod, Bowen's disease

\author{
Address for correspondence \\ Dr Eliz Aryal Rajouria \\ Dept of Dermatology \\ Kathmandu Medical College Teaching Hopital. \\ Sinamangal, Kathmandu \\ Email: eliz_aryal@yahoo.com
}

\section{Introduction}

Bowen Disease (BD) is a form of intraepidermal (in situ) squamous cell carcinoma (SCC), originally described in $1912 .{ }^{1}$ Exposure to solar radiation and arsenic are commonest cause for BD. ${ }^{2,3}$ Imiquimod $5 \%$ cream can be used as monotherapy or in combination with other modalities of treatment for BD. As Nepal is agriculture country, where pesticides, in form of environmental arsenic are being used.

\section{Case Report}

A 65 years female agriculturist by occupation from Ramechap, Nepal presented in Dhulikhel Hospital department of dermatology in June 2014, with history of non healing, tender lesion on right inner aspect of thigh from three years. She was treated at local health post and was not responding to any oral and topical medication. The initial lesion was a small, red, scaly rash which gradually increased in size with an irregular margin and overlying scales. The patient was otherwise well, only complaining of pain over right thigh (Figure1).

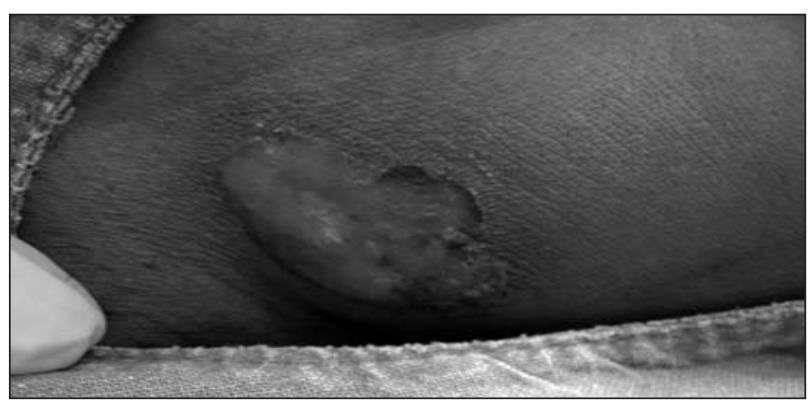

Figure 1: Well demarcated erythematous plaque, $3 \mathrm{~cm} \times 3 \mathrm{~cm}$ with irregular margin with crusts present over the middle of right inner thigh.

On cutaneous examination well demarcated erythematous plaque $3 \mathrm{~cm} \times 3 \mathrm{~cm}$ with irregular margin with crusts present over the middle of right inner thigh. On palpation the plaque was indurated and tender. There was no oozing, pus discharge or bleeding. 


\section{Case Report}

On laboratory examination complete blood count, peripheral blood smear, liver and renal function test, chest x-ray, mantoux test, HIV was within normal limits, direct microscopic examination of skin scraping in 10\% Potassium Hydroxide was negative for fungus. Histopathology of skin biopsy showed squamous epithelial cell with pleomorphic hyperchromatic nuclei and scanty to moderate amount of eosinophilic cytoplasm in epidermis. The lining cell shows loss of polarity and atypical nuclear changes seen in complete thickness of epidermis. No invasion seen with mild chronic inflammatory cells infiltration in superficial dermis (Figure 2).

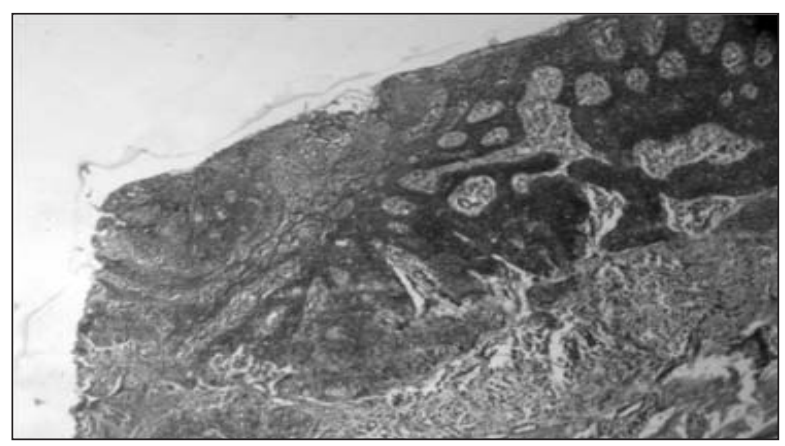

Figure 2: Histopathology shows squamous epithelial cell with pleomorphic hyperchromatic nuclei and moderate amount of eosinophilic cytoplasm in the epidermis. The lining cell shows loss of polarity and atypical nuclear changes seen in complete thickness of epidermis.

BD was treated with 5\% Imiquimod cream three times a week for three months followed by maintainence with croytherapy (liquid nitrogen) in every two week for next three months (Figure $3)$.

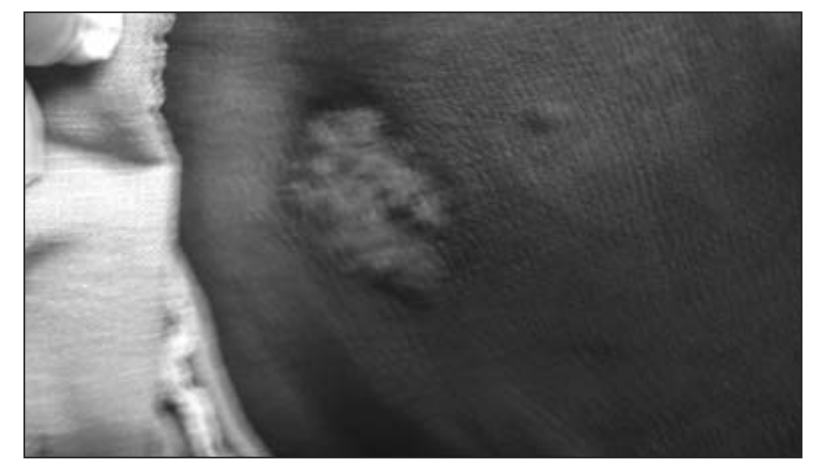

Figure 3: During course of treatment size and thickness decreased with mild atrophy and pigmentation.

\section{Discussion}

Bowen's disease is a precancerous dermatosis, first described by John T. Bowen in 1912. BD is considered white skin dermatosis present over sun exposed skin. ${ }^{1}$ However, our patient has Fitzpatrik skin type V. Similar cases were reported from Nigeria. ${ }^{4}$ Nepal being an agriculture orientated country where pesticides are being used a lot. Arsenic and its compounds, especially arsenic trioxide, are used in the production of pesticides. Usually organic arsenic is a highly stable chemical but in the environment it can oxidize and dissolve in water and thence pollute ground water. ${ }^{5}$ Water from wells have high percentage of arsenic.

Arsenicism may lead to hypopigmented or hyperpigmented patches with diffuse hyperkeratotic papules over both exposed and unexposed skin. Arsenic contamination usually causes lesions over the unexposed skin. Similarly, in our patient, the lesion was present over the inner aspect of thigh. The Ministry of Environment of Nepal has done a survey regarding presence of phenylarsenic oxide (PAO) in soil and water in Terai (Southern) belt region of Nepal. ${ }^{6}$ However, similar studies concerning PAO have not been conducted in the Siwalik/Chure (mountainous) region of Nepal. Moreover, we could not find other patients with BD in Ramechap district. Patients with BD may visit hospitals for health or cosmetic concern. Arsenic level can be detected in blood and urine but our patient was not compliant to do the examination for economic reasons.

In our patients we used imiquomod 5\% cream three times a week for three months. Topical Imiquomod is not available in Nepal. The samples of imiquomod cream were provided to us by a dermatologist from Germany who had visited to our hospital for observation. After three months of therapy, we had used up all the provided samples and thus the treatment was maintained with croytherapy (liquid nitrogen) fortnightly for next three months. After one week of therapy, patient had developed dermatitis to imiquimod which was controlled by application of topical 


\section{Case Report}

mild potent steroid for a week. Imiquomod activates immune cells like langerhans cell, natural killer cells, macrophages and B-lymphocytes through the toll-like receptor by secreting cytokines, interferon- $\alpha$ (INF- $\alpha)$, interleukin- 6 (IL-6) and tumor necrosis factor- $\alpha$ (TNF- $\alpha)^{7,8,9,}$ Successful treatment with Imiquomod as monotherapy has been reported from Denmark and USA. ${ }^{10,11 .}$

The lesion progressively decreased in size and thickness. At the three-month' follow-up after starting topical imiquimod, the lesion had flattened with persisting pigmentary changes. Imiquimod was stopped at this stage and cryotherapy was continued for another three months. A repeat biopsy at seven months revealed a normal epidermis. Cryotherapy was stopped and the patient was advised to be in regular follow-up every month. After nine months, the lesion had completely cleared with mild atrophy and pigmentation (Figure 3).

The patient is still under follow-up, but there has been no recurrence of the lesion at the end of two years. Cryotherapy was performed using a liquid nitrogen (-196 C) spray giving two freeze-thaw cycles, each freeze cycle being maintained for 510 second after the formation of an ice ball to the intended margin causing intra-extracellular ice formation with ischemia caused vascular stasis and damage. In our patients we use cryotherapy as maintenance in every second week. Similar case was reported from India where they use imiquimod topically along with weekly cryotherapy as maintenance. ${ }^{12 .}$

In conclusion, Dermatologists need to bear in mind that Bowen's diseases can be present in various form in skin type V, VI. In developing country like Nepal where imiquimod is not available; we can use cryotherapy, as a monotherapy for bowen's disease. Arsenic level need to be examined from all part of country.

\section{Acknowledgment}

The author would like to thank Prima Dr Hans Schiessler from Germany for his guidance and providing Imiquimod 5\% cream.

\section{References}

1. Bowen JT. Precancerous dermatosis. J Cutan Dis 1912; 30: 241-55. http://dx.doi.org/10.1111/1523-1747.ep12475717

2. Campbell C, Quinn AG, Ro YS, Angus B, Rees JL. p53 mutation are common and early events that precede tumor invasion in squamous cell neoplasia of skin. J Invest Dermatol 1993; 100: 746. http://dx.doi.org/10.1038/jid.1961.127

3. Graham JH, Mazzanti GR. Helwig EB. Chemistry of bowen's disease relationship to arsenic. J Invest Dermatol 1961; 37: 317-32.

4. Yahya H, Mohammed A. Bowen's disease: report of a case in a Nigerian man. West Afr J Med 2005; 24: 350-1.

5. Yamaoka H, Ikoma N, Kato M, Akasaka E, Tamiya S, Matsuyama T, et al. Multiple Bowen's disease in a patient with a history of possible arsenic exposure: a case report. Tokai J Exp Clin Med 2011; 36: 53-7. http://dx.doi.org/10.1081/ESE-120016888

6. Shrestha RR, Shrestha MP, Upadhyay NP, Pradhan R, Khadka R, Maskey A, et al. Groundwater arsenic contamination, its health impact and mitigation program in Nepal. J Environ Sci Health A Tox Hazard Subst Environ Eng 2003; 38: 185-200.

7. Hemmi H, Kaisho T, Takeuchi O,. Small anti-viral compounds activate immune cells via the TLR7 MyD88-dependent signaling pathway. Nat Immunol 2002; 3: 196-200. http://dx.doi.org/10.1038/ni758 


\section{Case Report}

8. Bilu D, Sauder DN. Imiquimod: modes of action. 2003; 149(Suppl 66): 5-8. http://dx.doi.org/10.1046/j.0366-077X.2003.05628.x

9. Miller RL, Gerster JF, Owens ML, Slade HB, Tomai MA. Imiquimod applied topically: a novel immune response modifier and new class of drug. 1999; 21: 1-14. http://dx.doi.org/10.1016/S01920561(98)00068-X

10. Danielsen AG, Sand C, Weismann K. Treatment of Bowen's disease of the penis with imiquimod 5\% cream. Clin Exp Dermatol 2003; 28: 7-9. http://dx.doi.org/10.1046/j.1365-2230.28.s1.3.x

11. Taliaferro SJ, Cohen GF. Bowen's disease of the penis treated with topical imiquimod $5 \%$ cream. J Drugs Dermatol 2008; 7: 483-5.

12. Patel KP. Bowen's disease treated with imiquimod and cryotherapy. Indian J Dermatol 2012; 57: 239-41. http://dx.doi.org/10.4103/0019-5154.96217 